\title{
Self-directed Teacher Professional Development in Saudi Arabia: EFL Teachers’ Perceptions
}

\author{
Hamad I. Alshaikhi \\ Al-Qunfuthah Educational Directorate, KSA
}

\begin{abstract}
This study explores Saudi EFL teachers' perspectives, attitudes and experiences with regards to their teacher professional development (TPD) with special emphasis on workplace learning and self-directed initiatives. Using semi-structured interviews and reflective essays, the study managed to highlight a thriving workplace learning context in which teachers are involved in many forms of self-directed learning, including experiences stemming from the dailiness of the everyday realities of their schools. Data showed that Saudi EFL teachers are committed professionals who are well aware of a variety of TPD resources and opportunities; some of them are institutionalised while the majority are self-directed by teachers themselves beyond any institutional requirement. The study revealed that many participants had high preferences for self-directed learning over institutional provisions for its embeddedness in their context, the nature of their specialisation, and for the changing nature of their profession. Networking, collaboration, reflection and collegiality are some of the main features of self-directed learning as reflected in teachers' current practices.
\end{abstract}

Index Terms-professional development, professionalism, language teacher education, EFL teachers, selfdirected learning, workplace learning, CPD

\section{INTRODUCTION}

Since English is neither a lingua franca for Saudis, nor is it the official language in the public education system, Saudi EFL teachers can be considered, in some cases, the single most important source of linguistic input for students (Al-Seghayer, 2011). Realising this fact, a considerable degree of professionalisation has taken place in the field of English language teaching and learning over the last few years in KSA as is the case worldwide (see Moskovsky \& Picard, 2019). Our government began to see the centrality and importance of EFL teachers and teaching to effective participation in global economy. This triggered an increasing demand for competent and qualified language teachers and for effective approaches to prepare them (see Richards, 2008).

However, a review of literature of TPD content and delivery models in the Saudi EFL context, coupled with my personal experience as an EFL teacher, reveal that TPD initiatives fall short from an ideal model of TPD (Alharbi, 2011; Al-Hazmi, 2003; Al-Hazmi, 2017; Alsalahi, 2015; Al-Seghayer, 2011; Alshaikhi, 2018; Assalahi, 2016; Elyas \& Al Grigri, 2014; Sywelem \& Witte, 2013). Career enhancement opportunities available to Saudi EFL teachers are mainly limited to one-shot training events and workshops (Al-Seghayer, 2011). These traditional TPD methods have been described as centralised, scarce, and ineffective; and usually consist of 'one size fits all' packages that are theoretical in nature (Al-Hazmi, 2003).

Further, these programmes do not provide hands-on, experiential and practical activities that can be directly linked to classroom reality. As a TPD approach, training programmes and workshops were shown to have limited success, as many teachers failed to develop and practice what they had learned during the training (Alshaikhi, 2018). As such, it seems that TPD opportunities available to EFL teachers in our context are incompatible with the vision implied by the reform agenda pressing for a fundamental change in teachers' practice and the way they acquire knowledge.

Of special relevance is the nature of our educational context itself, which plays a significant role in determining the nature of TPD and the construct of the teachers' professional identities. Saudi EFL teachers operate within a deterministic top-down educational policy that neither recognises teachers' voices, nor perceives teachers as real partners in the educational process (Alfahadi, 2012; Alnefaie, 2016; Alsalahi, 2015; Assalahi, 2016; Al-Seghayer, 2011; Mullick, 2013). Based on my extended experience in the Saudi context, Saudi EFL teachers' voices have always been neglected in initiating or conceptualising educational reform in our context. Such oppressive and exclusionary practices push teachers into a technical educational reality and confined their roles to that of curriculum implementers and passive technicians (Kumaravadivelu, 2003; Mullick, 2013).

An important element closely related to the above discussion is teachers' engagement with forms of self-directed TPD which seems to be devalued and neglected in our context (see Al-Seghayer, 2014; Alshaikhi, 2018). I have noticed that most of the previous studies that investigated TPD in our context have primarily concentrated on the Ministry of Education (MoE) as the main provider of TPD (see Alshaikhi, 2018). Overall, the emphasis has mainly been on institutionalised forms of TPD. However, I do believe that research has to pay equal attention to the teachers, as they can also initiate a more valuable form of TPD (i.e., self-directed TPD). This is especially important due to the huge advancements in information technology wherein more meaningful, interactive, and affordable forms of learning can be 
accessed by teachers. Furthermore, based on my experience, structures and support for workplace learning have not been given due consideration nor has the value or the impact of this kind of learning on teachers' practices.

Therefore, it could be argued that TPD, in its broadest scope, has not been fully investigated in the Saudi context. These observations raised numerous questions in my mind and triggered my interest to further investigate TPD among Saudi EFL teachers with special emphasis on self-directed TPD and workplace learning. My interest is also driven by my own belief that our understanding of TPD could be much broader than the limited scope adopted by many previous studies and as shown in the MoE's approach to TPD as discussed above. Hence, I decided to undertake this study with special interest in teachers' perspectives as told by themselves searching for an answer to the following question: to what extent are Saudi EFL teachers ready to engage with self-directed TPD?

\section{LITERATURE REVIEW}

\section{A. Traditional TPD}

Traditionalist approaches to teacher development imply a technical- rational approach to teacher professionalism wherein teachers are requested to apply knowledge and theories supplied by others to their own contexts (see Hayes \& Chang, 2012; Verloop et al. 2001). This conventional conception of teacher professionalisation reflects a deficit model of TPD (Sandholtz, 2002; Lieberman, 1995). Deficits in teachers' knowledge and skills are traditionally determined by external experts leaving teachers as objects rather than subjects of their development (Huberman \& Guskey, 1995). This approach resonates with a managerial professionalism discourse that seeks to dominate teachers' practices through mandated change, prescriptive curricula, standardization, accountability, and demands for effectiveness. (Day \& Sachs, 2004; Kennedy, 2014).

In-service training has been the most dominant form of traditional TPD in recent years (Al-Lamki, 2009; Friedman \& Phillips, 2004; Kennedy, 2005; Wallace, 1991). It is a direct intervention strategy, whereby discrete chunks of knowledge and skills are transmitted to teachers via external expertise; the mastery of which, it is presumed, improves teachers' competence and effectiveness (Freeman,1989). One of the main values of this approach to TPD is its ability to give practitioners an opportunity to consider their existing practice from a new perspective. This is basically based on the assumption that teachers' existing beliefs and assumptions about teaching and learning may constrain their growth and obstruct their innovation (Kennedy, 2005; Timperley, 2008). Training is also a good technique to implement large-scale educational reform (Hayes \& Chang, 2012; Richards, \& Farrell, 2005). However, it is more effective at establishing its aims if built on teachers' actual needs and models practically the behaviours teachers are expected to implement (Hayes \& Chang, 2012).

However, training has been heavily criticised for maintaining a narrow view of teaching and learning (Garet et al., 2001; Kennedy,2005). Training is normally top-down in nature and supports a "skills-based" model of teacher education where content is delivered to teachers by outside experts with an aim of updating their skills so that their competence is improved (Kennedy,2005). It is also compatible with a "standards-based" view of teacher education wherein the focus is on standardisation and coherence to ensure that teachers' performance is in agreement with national standards (Kennedy,2005). In addition, the training model offers a perspective that is compatible with a techinicist view of teacher education (Craft, 2000). Teachers, according to this perspective, are reduced to passive technicians or knowledge transmitters whose primary duty is to implement educational reform as envisaged by the educational authority (Kumaravaddivelu, 2003; Benson, 2001). Lastly, training has been criticised for its inability to satisfactorily bridge the gap between theory and practice as well as between what teachers learn and the realities of their classrooms because it normally takes place in a decontextualized manner (see Kennedy, 2005; Wallace, 1991).

\section{B. The Growth Paradigm}

Recent educational reform initiatives coupled with new conceptions of teaching and learning require teachers to change their practice, adopt new roles and teach in ways they have never experienced before. The realization of this vision of educational practice, according to Darling-Hammond \& McLaughlin (1995), may not be obtained through "traditional top-down" TPD. It requires a shift towards new concepts of teacher learning that are attentive to the dynamic, complex and multifaceted nature of teaching and learning (Broad \& Evans, 2006; Mitchell, 2013; VillegasReimers, 2003).

This growing acceptance of teaching as a distinct profession that is dynamic, and complex coupled with the acknowledged limitations of traditional approaches to TPD led many educationists to shift their thinking from training to learning (Broad \& Evans, 2006; Darling-Hammond \& McLaughlin, 1995; Kelchtermans, 2004; Marsick, \& Watkins, 2015; Mitchell, 2013; Richards, 1998; Villegas-Reimers 2003). In search for a paradigm that suits the complexity of the teaching profession, teacher educators drew upon theoretical models derived from concurrent advancements in cognitivism and constructivism. This gave rise to the growth paradigm (Huberman \& Guskey, 1995) or the aspirational model of teacher education (Day \& Sachs; 2004) which shifted the focus of TPD approaches from a top-down perspective to a more bottom-up approach, that acknowledges the centrality and importance of teachers' experiences and ways of knowing to their development, wherein teachers are seen as active learners who initiate and design their own development activities based on their contexts (Crandall \& Christison, 2016; Desimone, 2009; Johnson, 2009a).

Thus, the growth paradigm is seen as a countervailing model to conventional approaches to TPD that have dominated 
teacher professionalism for a long time (Huberman \& Guskey, 1995; Kennedy,2005; Wallace, 1991). It consists of a variety of site-based professional learning opportunities. They are interactive forms of development that conceive of teachers as active agents of their TPD. External expertise plays a minor or no role in the creation or direction of these learning events and schools are acknowledged as learning sites (Smylie, 1995; Huberman \& Guskey, 1995).

Therefore, TPD, in its widest perspective, means more than mere acquisition of new skills and knowledge. Rather, it is a process of continuous learning beginning with pre-service teacher education and continuing throughout teachers' careers (Day, 1999). Its main focus should be on "deepening teachers' understanding of the processes of teaching and learning and of the students they teach" (Darling-Hammond \& McLaughlin, 1995). This new approach to TPD see the process of development as a transformative undertaking of continuous reflection and critical reflection that leads to changes in practitioners' views, attitudes, habits and practices (Kerka, 2003).

Knowledge acquisition within the growth paradigm of TPD is contextualised, participant-driven and constructivist in nature (Darling-Hammond \& McLaughlin, 1995; Johnson, 2009b). This can be achieved by shifting the focus from "direct teaching" to facilitating "in-school learning (Lieberman, 1995) wherein teachers are engaged in concrete tasks related to their classroom practices including but not limited to teaching, reflection, assessment, and observation (Lieberman, 1995; Timperley, 2011a ;Villegas-Reimers, 2003). This active participation paves the way for teachers to bridge the gap between theory and practice that has always been posed by traditional in-service models of TPD (Darling-Hammond \& McLaughlin, 1995).

\section{Self-directed Learning}

As opposed to traditional TPD activities which view learning as a dissemination of information and position teachers as passive recipients of expert knowledge, learning in a self-directed manner is compatible with the principles of the growth paradigm discussed above as it recognizes the central role of teachers as active participants and of their contexts as potential sources of valuable kinds of knowledge (Raza, 2010; Smith, 2017). Self-directed TPD stands for the independent learning of teachers either individually or in groups. This often happens when teachers decide to pursue development at their discretion with or without institutional support using existing resources. In self-directed forms of TPD responsibility is laid on the shoulder of the teacher to set some TPD goals and to choose the appropriate kinds of activities that will help him/her establish these goals (see Villegas-Reimers, 2003). This form of learning is important in that it recognises the value and power of both "experiential and action-based learning" (Richards, \& Farrell, 2005 , p. 14).

Self-directed TPD can be carried out individually as is the case with self-monitoring, analysis of critical incidents, journal writing, and reflection. It can also be done on one-to-one basis such as peer coaching, peer observation, critical friends, and team teaching. In addition, it can be group based such as case studies, and teacher support groups. Further, it can be institutionally facilitated (Day, 1999). Some activities including action research fits all the previous categories.

A number of processes have been identified by Richards \& Farrell (2005) as central to self-directed learning. These involve inquiry where teachers keep asking probing questions about their daily practices; self-appraisal to assess one's teaching and development needs to determine his/her weaknesses and strengths; personal experience which provides the stimulus for learning; personal construction since the meaning is constructed by the learner himself/herself; contextualised learning because it takes place in a particular social context; and planning and managing because success of this kind of learning depends on the teachers' ability to set learning goals and to determine the strategies for attaining those goals.

\section{Workplace Learning}

The workplace context has become firmly established over the past decade as an important setting for ongoing professional learning as well as for inquiry into that learning (Forde et al, 2006). The centrality of workplace learning to successful continuing professional learning is widely recognized within the research community (Webster-Wright, 2009). Workplace learning is a general term used here to refer to all forms of TPD opportunities teachers engage with at the school level, be it formal or informal with or without assistance from external facilitators (see Avalos, 2011). The importance of workplace learning to professional growth in general and professional identity formation in particular is well established in literature (Forde et al, 2006). According to McLaughlin (1994) the most meaningful sort of TPD is that which takes place in the contexts of professional collaborative communities where teachers engage in meaningful interactions at their workplace contexts (see also Johnson; 2009b).

Although this form of development is often underestimated in many educational contexts, it is still considered to be a significant factor in the process of professional growth (Craft, 2002). A significant contribution of this source of knowledge lies in its ability to help practitioners bridge the gap between theory and practice (see Wilson \& Demetriou, 2007). Indeed, it is in the workplace context that professionals live the experience of being part of a professional community. Learning alongside experienced professionals is important especially for new teachers during the phase of initiation into the teaching profession (Forde et al., 2006). The process of transition from the university into the school context is not an easy straightforward process. Although novice teachers graduate with a good stuck of codified knowledge (content knowledge) relevant to their practice, it is in the workplace context that they develop their context specific knowledge which is necessary for the process of development (Eraut,2004). This is the type of professional knowledge that is not easily codified and presented in textual forms. Rather, it is practical in nature and usually " 
acquired informally through participation in social activities;" and that most practitioners are unaware of its influence on their behaviour and practice (Euraut, 2004, p.263). Thus, one of the main values of this kind of learning is the emphasis it places on teacher practical knowledge as opposed to traditional institutional training events where the focus is on codified knowledge determined by experts extraneous to the field of teaching (Smith, 2017)

\section{E. Adaptive Expertise}

In developing a high-level guiding framework for the professional learning of teachers and school leaders throughout Australia, Timperley (2011b) promotes a flexible notion of democratic professionalism wherein teachers are being viewed as "adaptive experts" working in environments of high adaptive capacity (see also Timperley, 2011a). Solving educational problems, as she argues, requires "transformative" rather than "additive" change to teachers' practices (p. 5) and this can only be supported through the internal processes of learning which requires active engagement on the part of the teacher in democratic professionalism contexts (Day \& Sachs, 2004).

"Adaptive", as highlighted by Timperley (2011a), implies a dynamic process of ongoing learning and adjustment. Adaptive experts are self-regulated learners who have adequate mastery of content knowledge, pedagogical content knowledge, and who also have high adaptive capacities. They are highly aware of their deeply ingrained assumptions, beliefs and values, and the way these impact on or inform their practice. Their professional knowledge is built on constant assessment and analysis of their students' needs and thus adjusting their expertise accordingly in order to be responsive to those needs. Their knowledge is in a state of flux and constantly changes according to the challenges facing them and their students.

Ongoing professional learning is the theoretical framework underpinning this form of professional identity wherein knowledge is constructed by teachers themselves through active engagement in contextualised learning opportunities (Timperley, 2011a, 2011b). Such framework is reflected in the growth paradigm which is characterized by diversity and variation that is suitable to the vocation of teaching and to the teachers as agents of change (Kelly, 2006; Sachs, 2016). This multiplicity of learning opportunities, in Timperley' (2008) view, is essential to change teachers practice because it helps teachers absorb new knowledge easily and translate it effectively into practice.

\section{METHODOLOGY AND MeTHODS}

A qualitative exploratory research design was chosen for this study. This choice supports my general aim of investigating teachers' personal perceptions, attitudes, and experiences regarding their self-directed TPD. As per literature, the focus within qualitative research is on the socially constructed reality and the multiple meanings that research subjects ascribe to it (Creswell, 2013; Denzin \& Lincoln, 1998). To achieve this end, researchers need to use appropriate research methods that enable them to capture people's contextual meanings and actions from within so that they can develop an insider perspective into the research focus (Seidman, 1998). To develop this perspective within my study, I utilised semi-structured interviews and reflective essays to probe the depth and breadth of my research focus from the perspective of 25 practicing Saudi EFL teachers (male and female) in Saudi public schools who have been purposively invited to participate.

A reflective essay is one type of personal documents involving written accounts of a participant's experiences and reflections regarding his/her own TPD (Taylor et al., 2016). The essays were semi-structured in nature in that, upon receiving participants' reflections, I commented on and/or asked for further clarification or elaboration on issues that needed to be enlarged for a better understanding and in-depth investigation. This method was also used with some male and female teachers to further discuss issues that have not been fully discussed during their interviews.

Most semi-structured interviews and essays were conducted in Arabic for simplicity and as requested by the participants. All interviews and essays were first transcribed verbatim and then sent to the participants for validation (Creswell, 2013; Maxwell, 2005). Both inductive and deductive analysis techniques were employed to thematically analyse and code data using Braun and Clarke's (2006) model as a guide. Their proposed six-phase thematic analysis model provided a general framework and a sense of direction throughout the process of data analysis:

1- Familiarisation with the data.

2- Generation of initial codes.

3- Searching for potential themes.

4- Reviewing the themes.

5- Defining and naming the themes.

6- Writing the report

However, due to the bulk and complexity of my dataset, I decided to use a computer programme (MAXQDA) for storage, management, organisation, classification, coding, and easy access. The programme proved to be both helpful and useful. For example, it helped me easily cluster codes into categories and enabled me to easily allocate each quote to its particular category. Furthermore, the programme enabled me to enter many coded data under different categories without losing track of my data.

Consent and confidentiality

Prior to any involvement of the participants in the study, all of them were sent consent forms and participant information sheets to ensure they understand the purpose, aims and benefits of the study they will take part in. 
Participants were assured of strict confidentiality and non-identifiability (Berg, 2009). All of them agreed voluntarily to participate in the study and signed the forms.

\section{FINDINGS}

Two main themes emerged from the data each of which has a number of subthemes as can be seen below:

Theme 1: General perspectives

TABLE 1

THEMES EMERGING FROM DATA REGARDING GENERAL PERSPECTIVES

\begin{tabular}{|l|l|}
\hline Subtheme & Example quote \\
\hline Importance of TPD & $\begin{array}{l}\text { "You won't find anyone who denies the important of TPD to English teachers. It is } \\
\text { important because it is a tool to improve the performance of the teacher." (Hani) }\end{array}$ \\
\hline Personal responsibility & $\begin{array}{l}\text { "[TPD] is the teacher's responsibility; We have to agree on this...the teacher has to } \\
\text { take the initiative himself." (Arif) }\end{array}$ \\
\hline
\end{tabular}

\section{Importance of TPD}

All participants emphasised the importance of TPD to their practice, as can be seen in Table 1. They unanimously agreed that TPD is an essential component of their practice. Participants like Mahmood gave TPD priority because they think it is "a fundamental principle" in teaching. Fayz, for instance, likened his need to development to his need for "food, water, and air" because it keeps him "professionally alive". TPD, as he continued, "deals with the spirit and the mind; and these need to feed just like the body." TPD was also emphasised for its ability to build teachers" confidence as can be seen in Mona's quote:

I found out that self-learning is a good way to improve teacher effectiveness; because it helps me develop the confidence I need to face the challenging problems and obstacles in my teaching career.

It has to be mentioned though that forms of learning driven by teachers themselves have been given special importance by all participants. They stressed the value of this form of development over institutional training because it is responsive to their needs, problems and contexts as was evident in the participants' reports. However, the majority of participants held that it was their specialisation as EFL teachers that made it imperative for them to prioritise selfdirected TPD. This linguistic component appears to be an indispensable aspect of EFL teachers' engagement with selfdirected TPD. Teachers' emphasis on their linguistic development was partly due to the nature of their job as language teachers and to the nature of English in their context. "English is a foreign language; if not used, then it will be forgotten," as stated clearly by Yassir. Therefore, EFL teachers, according to his opinion, have to continuously work hard on their language, otherwise they are at risk of losing it. Ali, who strongly agrees with Yassir confirms this point saying:

the linguistic aspect is one of the most important issues that the language teacher have develop. And this entails continuous engagement with TPD inside and outside the school.

Continuous engagement with self-development is also important to participants because it provides them with better pedagogical practices, sound decision making, and appropriate teaching techniques to deliver their textbooks effectively:

There are lots of ways to deliver the information to your students, but not every teacher can do that...the one who learns new strategies and understands them well and always changes his style is the one who will certainly achieve the highest student engagement and achievement. And this can be acquired by the teacher's ongoing search for the best (Faris).

Part of teachers' justification for the importance of ongoing engagement with TPD is adaptation to change. Their accounts imply that they are fully aware of the changing nature of their profession and therefore they have to continue learning in order to increase their readiness. The teacher, according to Mansour, "needs to develop himself according to the latest advancements; and according to the new trends which may accompany his profession". Any teacher, as he observed, has to "keep up with these things" throughout his career, otherwise he will be lagging behind.

Personal responsibility

The majority of participants agreed that it is the teacher himself who should take the responsibility of ensuring that his skills, knowledge, and abilities are up to date. Arif's quote (see Table 1) is just one example that is representative of many others. Even those who think TPD should be a joint responsibility between the teacher and his institution explained clearly that teachers are not excused from pursuing development if their institutions failed to cater for their needs:

we should not throw the load on others...If the Ministry does not provide training to me or if the supervisor has other tasks to do, does this give me the right to stop developing? (Yassir)

Teachers' justification for this stance centred on four main arguments. First, they believe that information can now be easily accessed and that any teacher "can dispose of everything around him" and develop himself easily without any institutional support (Fayz). Second, participants feel that the MoE is not doing well in terms of developing its teachers; therefore, the teacher should take the initiative himself instead of idly waiting for others to develop him. Typical of others, Hassan explained this saying: "you may not get what you need from the MoE; and even if you managed to get it, it is not as good as you expect." 
The third argument implicit in teachers accounts states that development is part of the act of teaching and therefore it is natural for the teacher to keep on learning until retirement. TPD, as stressed by Sameer, is "a life-long process" and "teaching is the profession of learning". The final argument, as explained by Adnan, emphasised that the teacher is "the only person who knows his weaknesses well" and therefore he is the only one who can diagnose those weaknesses accurately and look for suitable ways to treat them. However, this responsibility has to coincide with institutional support as stressed by participants.

\section{Theme 2: Current TPD practices}

TABLE 2

THEMES EMERGING FROM DATA WITH REGARDS TO SELF-DIRECTED TPD

\begin{tabular}{|l|l|}
\hline Subtheme & Example quote \\
\hline Learning from practice & $\begin{array}{l}\text { "the actual practice of teaching is a source of teacher development... I always discover mistakes } \\
\text { and find new ways to deliver information through my daily practices" (Faris) }\end{array}$ \\
\hline Using the internet & $\begin{array}{l}\text { "the best way of learning nowadays is through the internet. We learn everything. Everything. If you } \\
\text { search the internet for any question, you will definitely find an answer. It is the only tool that can } \\
\text { meet all of my needs at any time." (Hassan) }\end{array}$ \\
\hline Learning from colleagues & $\begin{array}{l}\text { "when I feel that something gets difficult for me, or if I did not find what I am looking for, or if I } \\
\text { did not recognize something fully, the first choice for me is my colleague himself." (Hatim) }\end{array}$ \\
\hline Reading & "I develop myself through the act of reading" (Adnan) \\
\hline Social networks & $\begin{array}{l}\text { "I use social networks to benefit from other teachers and to share my knowledge...use of personal } \\
\text { learning networks has the greatest impact on my TPD" (Mona) }\end{array}$ \\
\hline Postgraduate studies & $\begin{array}{l}\text { "Formally, I studied at Al-Baha University. I studied there. And I had a master's degree in applied } \\
\text { linguistics." (Adil) }\end{array}$ \\
\hline Paid formal courses & $\begin{array}{l}\text { "I enrolled in many institutes where I took training courses. I paid for them myself; and I travelled a } \\
\text { lot although I do not like travel." (Sadiq) }\end{array}$ \\
\hline
\end{tabular}

\section{Learning from practice}

All participants indicated that their daily practices and their ongoing engagement with their students represent a major source of development for them (see Table 2). Proof of this can also be found in Yassir's words who said: "undoubtedly the classroom is a major source of learning because a student or a particular situation might generate a new experience to you." Each year, according to his perspective, was unlike the previous one because his classroom encounters always refine and improve his skills and teaching styles. Participants' learning in this case is supported and sustained by their ongoing trails and pursuit of new methods and better ways that work for them and their students.

Furthermore, teachers reported that assuming new roles inside schools was another source of development. This was highly emphasised by secondary school teachers who were sometimes given some administrative roles inside their schools. Ali, for instance, worked as an "academic advisor" at his school and claimed that "assuming this post is effective and develops the teacher as well."

In addition, working with students on school projects has also been identified as a source of learning for some teachers. Adil, for instance, reflected on the days when he started a student club inside his school and recalled how that experience had enriched him and how his students had lifted him up with them:

we used to sit together, talk, and make different activities. We also used to present different programmes at the school level...but for me, when we used to sit and talk it was like sitting with other teachers. They come up with different things and expressions which I don't know. Their level was very high, and they lifted me up with them.

Many participants also described reflection as a tool of learning. They explained to me how the ability to think about and reflect on specific aspects of their practice helped them improve their performance and informed their future decisions. Faris for instance, was one of the teachers who referred to the role of reflection in his development when he said "reflection improves my performance; this is real... I always sit privately and criticise myself." Mahmood also adopts a critical attitude to his classroom behaviour and performance as can be seen below:

I ask myself: why did the student do that? I discuss it within myself and sometimes find answers. My method might have been wrong. The questions might have been asked incorrectly. My attitude to the student might have been unsuccessful. This makes me learn from my mistakes and change for the best.

\section{The internet}

The internet was another choice for many participants in terms of self-development. It provided them with an affordable and easy platform where they can network, seek help and sustain their professional learning. Hassan's quote (see Table 2) is just one example to illustrate this point. Arif, among others, described the internet as being one of "the best things for self-learning because it can provide whatever teachers need immediately and in the easiest manner." In terms of their personal experience, many participants explained to me how they used the internet to improve their pedagogical practices so that they can deliver their content properly. Barakat, for instance, explained that he "always browse for strategies and try to watch videos demonstrating their use in websites and YouTube." This was also echoed by Hatim who always uses YouTube to see how other teachers conduct their lessons.

The internet also provided teachers with ready-made material that could be used in their classes. This feature saved them both time and energy. Some participants, for example, visit websites like "Saudi English" to exchange expertise with others and to download materials related to their subject such as "new experiences, explanations, examples, ready- 
made tests... and teachers' books" as pointed out by Mansour.

Further, the internet gave some participants an opportunity to personalise and customise their development according to their own specific needs. One of those needs, as was evident to me, was their linguistic proficiency; and the internet was the ideal source for linguistic development. Barakat, for instance, described to me how he benefited from the internet in developing his language through "live chat with natives."

\section{Learning from colleagues}

Hatim's quote (see Table 2), and many others similar to it, show that learning from and with colleagues has always been an integral part of participants' professional growth. Many participants described in their reports how they work collectively and in a collegial manner to address various issues related to their classroom practices:

We collaborate on many things. We benefit from each other. We try to work together to use things and technologies. We do that a lot. For instance, we started to gather low-performing students together in small classes and we give each one of us a specific area to address based on his specialisation (Hassan).

Sadiq, among others, also stressed the importance of informal collegial chats to his growth. Adil reported to me how he and his colleagues would chat informally on various aspects of their daily practices and how those talks enriched their repertoires. In a similar manner, Mahmood explained to me that he is always keen to mix with other teachers in the breaks to chat informally about many topics related to their practice. Those chats were highly important to him because "a friend might bring up an idea and you take it and benefit from it in your class" as he explained.

Informal classroom visits were another form of voluntary collegial development inside schools where teachers observe and being observed by their colleagues. Although most of those visits happen between EFL teachers themselves, there were some instances of classroom visits to teachers from other disciplines. This can be seen in Ali's description of the following experience:

I visited the biology teacher and I benefited from the way he controls his class, the way he directs questions, and the way he arranges [the lesson].

Although most of this collaboration remained at the level of talking about practice and advice giving, there were some hints that teachers' collaboration sometimes goes beyond mere talk and extents to joint work on issues of mutual interest inside schools as was evident to me at Hassan's school.

\section{Reading}

Reading was another source of development for some participants (see Table 2). Describing his lived experience, Majdi explained to me how he sometimes resorts to reading to enhance his linguistic competence. He reported to me one of his experiences when he came across a book on language development at "Jareer Bookstore." The book was "comprehensive" and "talks about everything in language." It was a milestone in his development because it taught him how to function in different situations as he claimed. Adil also pointed out that he is "a big fan of reading." However, the act of reading at his school was rather collaboratively organized. He explained to me that he and some of his friends had started a small "English reading club" where they normally meet three times a week "outside school" to "read and discuss" a book that has been decided by the group. Essa was also interested in learning more about innovations in his field. His reading focuses on "specialised teachers' outlooks and their ways of innovation in other countries."

\section{Social networks}

Some participants resorted to online social networking in order to learn and exchange expertise as can be seen in Mona's excerpt (Table 2). Mona stressed the value of social networking to her practice because it kept her connected to the wider community around her. Ibrahim was another teacher who used social networking to develop his practice. He justified his emphasis on this type of development because "there is an exchange of expertise and a diversity of cultures; and you may communicate with people who may enrich your knowledge." Social networks are also a source of linguistic development for participants as is the case with Sameer who uses twitter for this purpose. He also referred to Facebook where he has connections with English speaking friends.

However, it has to be mentioned that WhatsApp has been the most widespread tool of communication amongst EFL teachers. Each educational office has a special WhatsApp group for EFL teachers which is normally used for communication and development. I have been added to one of those groups and I have experienced first-hand how teachers engage informally with one another in lively discussions about their daily practices. However, some teachers have been critical of their WhatsApp groups because they have been mainly used formally as is the case with Adil. Other groups, in other areas, have been criticised for overuse of Arabic language.

\section{Postgraduate studies}

Enrolment in a postgraduate course is a source of development for some teachers. Adil (see Table 2) is one of the participants who joined a master's degree course at a local university which managed to expand his knowledge on many vital educational issues including "curriculum, students, and [the educational] environment in general." Sadiq, who also obtained a Master of Education from a local university, emphasised the importance of this source of learning to his experience saying that "it overturns balances and concepts." The following excerpt describes how he felt after obtaining his degree:

I can say that I am in full control of the syllabus and the proper methods and teaching skills to deliver

it. Thus, I find good interaction from my students 
Some teachers haven't engaged with this kind of development yet but have the intention to do so in the future as is the case with Arif and Ibrahim who are waiting for their opportunity.

\section{Paid courses}

Three participants talked about how they sought training courses beyond their institutions. Such courses are not normally offered in the areas where they live. Therefore, teachers have to travel to nearby cities in order to enrol in them as is the case with Sadiq (see Table 2). Sadiq's experience was also echoed by Adil who joined "Wall Street Institute in Jeddah" for two months where he underwent two extensive language courses. Ali enrolled in an online training course at "McMillan" to improve his linguistic competence. These three participants spoke extensively on how this form of development positively affected their professional lives and enriched their repertoires.

\section{DisCUSSION AND CONCLUSION}

In this article, I presented the findings of an exploratory small-scale study that aims to investigate the perspectives of Saudi EFL teachers about their self-directed TPD. As was evident from the data, the study identified a thriving practitioner workplace learning culture among participants. Teachers' reports showed a wide variety of self-directed forms of learning opportunities which they engaged with to improve their teaching practices. Some of the learning opportunities were inherently collaborative and collegial in nature; and others were individualistic. In addition, some of them were intentional while others were incidental and unplanned. This kind of learning, as was evident from participants reports, is less structured and involves learning from experience and other people either in-site or off-site (Eraut,2004; Lieberman,1995).

Therefore, contrary to some previous studies which noted that self-directed TPD was not highly recognised by teachers (see Al-Lamki, 2009; Friedman \& Phillips, 2004), participants of this study attached too much importance to it; and in some cases, it was the main venue of development that caters for their context specific needs. My participants showed a high preference for this form of learning over institutional provisions of TPD. The reason for this could be that teacher learning in a self-directed manner is participant-driven, constructivist in nature, and context-specific making it response to their immediate needs (Darling-Hammond \& McLaughlin, 1995; Smith, 2017). It was evident from data that teachers' selected self-directed TPD experiences provided occasions for hands-on learning opportunities that built both their content knowledge and pedagogical content knowledge. While institutional training is normally designed to transmit knowledge and skills to learners, self-directed TPD as practised by the study's participants changed their roles from passive recipients to active learners constructing their knowledge through reflection, collaboration, and networking (Alshaikhi, 2018). It engaged teachers actively in concrete tasks related to their classroom practice including teaching, assessment, and observation (Lieberman, 1995; Timperley, 2011a; VillegasReimers, 2003).

The study revealed that part of the participants' learning was socially negotiated. Participants spoke of the degrees to which their knowledge and skills were enhanced as a result of participation, communication, and collaboration. By active engagement in a community of learners sharing and discussing mutual concerns, teachers were able to build their understanding, develop their confidence and self-efficacy, and improve their practices. Such learning communities are important to teachers' practices because they involve teachers in collective work on authentic situations emerging from the "dailiness" of their practice (Lieberman, 1995). Therefore, it seems important to enhance this kind of learning in our future plans, support current communities, and increase schools' capacity for these learning structures.

Learning from practice was the most mentioned form of learning among the study's participants. It was valued for its immediate relevance to their contexts. When describing the main source of their growth, all participants referred to experiences stemming from the actual practice of teaching in their working contexts. This reflects the more individual and private and even unaided learning from daily classroom routines which helped teachers survive and become efficient in their classroom tasks. It produced a kind of knowledge that is "created in the context of application" (Day, 1999, p. 175), and therefore immediately applicable to teachers' contexts and problems. Therefore, the most powerful source of learning comes from the classroom itself through self-examination, observer-examination, reflection, or analysis of critical incidents (see Desimone,2009). This confirms one of Sandholtz's (2002) claims that teaching itself is one of the main experiences that profoundly influence teachers' practices as it provokes teachers to re-examine their approaches and teaching practices.

Part of teacher's learning came from reflection which is closely linked to their workplace learning. Participants managed to sustain a reflective approach to their practice and therefore, were able to make visible some aspects of their daily practices. Reflection, as practiced by the study's participants, created opportunities for ongoing learning, evaluation, and correction. This agrees with literature which emphasised that good teachers are reflective (Day, 1999; Richards, 1998; Wallace, 1991). Engagement with reflection, according to Day (1999) is a kind of inquiry that helps teachers understand themselves and improve their practices. In fact, it enabled some of the participants to be guided by informed decisions instead of mere intuition (see Richards, 1998).

Participants' engagement with development showed a movement towards collaboration and collegiality to combat isolation and de-professionalisation. My findings showed that participants are engaged in systematic and sustained learning processes in a community of learners in which they collaborate voluntarily and collegially with one another for the prime purpose of improving their practice. This collaboration was among teachers in the same school, across 
schools, and virtual. Collaborative teacher development, according to Johnson (2009b) is gaining recognition as an important "wellspring" of TPD. It also increases teacher agency and control on their learning because it supports a view of practitioners as legitimate knowledge producers (Johnson, 2009a). Learning within this conception is viewed as a collective process and results from co-participation in social practices through lived experiences (Fuller, 2007). Knowledge generated from such communities is said to be both sensitive to teachers' immediate contexts and relevant to their daily concerns and problems (Lieberman, 1995). In fact, professional learning communities were significant to my participants' development because they took into account teachers' immediate contexts (their schools), their actual needs, and their empowerment since they were given the chance to be active agents in their own development (see Kelchtermans, 2004).

The internet provided the study's participants with another informal and flexible platform for ongoing development. It extended their learning beyond their institution allowing teachers to network informally with virtual learning communities worldwide. This potential learning tool transcends time and context limitations allowing teacher to interact with various practitioners across the globe (see Alshaikhi, 2018; Raza, 2010). It was, in fact, a very important networking tool for the majority of participants because it managed to bring them together with other professionals to share ideas and address mutual problems. This move reflects agreement in literature on the positive role of communication and networking on teachers' self-confidence, motivation, engagement and practice (Garet et al., 2001; Crandall \& Christison, 2016; Johnson, 2009b).

However, it has to be mentioned that apart from the few instances wherein the study's participants described their engagement with self-directed TPD to improve their linguistic competence, most of the participants' engagement with self-directed TPD was implementation oriented wherein participants sought expert advice on the best available means to deliver their curricula. This is not surprising in our context given the rigid policy restrictions and the tight curriculum framework within which teachers operate (Alnefaie, 2016; Assalahi, 2016). Therefore, unless teachers are given more freedom and autonomy with regards to their teaching materials, teacher collaboration and networking may remain geared towards implementation rather than innovation (see Alshaikhi, 2018). It might also be the case where some teachers participate in community cultures and collaborative learning while continuing to use previous teaching practices (Day, 1999a). This brings to the discussion Kennedy's (2005) classification of TPD and that although some learning opportunities have the features of transformation, might serve transmissive agendas if set in educational policies that do not support transformation.

In summary, the study managed to bring to light a thriving workplace learning context wherein teachers are implicated in many forms of learning including experiences stemming from the everyday reality of their classrooms. This might imply that Saudi EFL teachers, as the ones in my study, are committed professionals who are well aware of a variety of TPD resources and opportunities; some of them are institutionalised while the majority are self-directed by teachers themselves beyond any institutional requirement.

Moreover, the data also showed that the study's participants have a good sense of themselves as responsible professionals who are willing to continually develop themselves to be better prepared for the challenges of their profession despite the abundance of demotivating factors and the passive identity the MoE imposes on them through its de-professionalising practices (see Alnefaie, 2016Al-Seghayer, 2011; Alshaikhi, 2018; Mullick, 2013). Indeed, my findings showed that the study's participants developed a conception of themselves as adaptive experts who see development as part and parcel of their professional responsibilities and who engage with it continually in their pursuit towards improving their students' achievement (Timperley,2011a). This attitude reflects a more democratic approach to teacher professionalism as opposed to the MoE's instrumental and managerial approaches to teacher effectiveness and professionalism (Assalahi, 2016; Day \& Sachs, 2004). However, an important observation about teachers' engagement with this type of learning was that some of their learning instances were still geared towards curricula implementation due to policy implications and rigid curricula constraints. Therefore, it is important to support this teacher identity by providing logistical and moral support in accordance with and through more consistent implementation of the existing policy structures.

\section{REFERENCES}

[1] Alfahadi, A. (2012). Saudi teachers' views on appropriate cultural models for EFL textbooks: insights into TESOL teachers' management of global cultural flows and local realities in their teaching worlds. Doctoral dissertation, University of Exeter.

[2] Alharbi, A. (2011). The development and implementation of a CPD programme for newly qualified teachers in Saudi Arabia. (Doctoral dissertation). Retrieved from https://eprints.soton.ac.uk (accessed 10/01/2020).

[3] AL - Hazmi, S. (2003). EFL teacher preparation programs in Saudi Arabia: trends and challenges. Tesol Quarterly, 37(2), 341344.

[4] Al-Hazmi, S. (2017). Current issues in English language education in the Kingdom of Saudi Arabia. Journal of Modern Languages, 17(1), 129-150.

[5] Alnefaie, S. K. (2016). Teachers' role in the development of EFL curriculum in Saudi Arabia: The marginalised status. Cogent Education, 3(1), 1-14.

[6] Alsalahi, S. M. (2015). Stages of teacher's professionalism: How are English language teachers engaged? Theory and Practice in Language Studies, 5(4), 671-678.

[7] Al-Seghayer, K. (2011). English teaching in Saudi Arabia: Status, issues, and challenges. Riyadh: Hala Print Co. 
[8] Al-Seghayer, K. (2014) The Actuality, Inefficiency, and Needs of EFL Teacher-Preparation Programs in Saudi Arabia. International Journal of Applied Linguistics \& English Literature, 3(1), 143-151.

[9] Alshaikhi, H. (2018). English Language Teacher Professional Development in Saudi Arabia: Teachers' Perceptions. Doctoral dissertation, University of Exeter.

[10] Assalahi, H. M. A. (2016). An inquiry into TESOL teachers' perspectives on professional development in the workplace at a university in Saudi Arabia. Doctoral dissertation, University of Exeter.

[11] Avalos, B. (2011). Teacher professional development in teaching and teacher education over ten years. Teaching and teacher education, 27(1), 10-20.

[12] Benson, P. (2001). Teaching and researching: Autonomy in language learning. London: Routledge.

[13] Berg, B. (2009). Qualitative research methods for the social sciences ( $7^{\text {th }}$ ed.). Boston: Pearson.

[14] Braun, V., \& Clarke, V. (2006). Using thematic analysis in psychology. Qualitative research in psychology, 3(2), 77-101.

[15] Broad, K., \& Evans, M. (2006). A review of literature on professional development content and delivery modes for experienced teachers. University of Toronto, Ontario Institute for Studies in Education.

[16] Burns, A. \& Richards, J. (2009). Introduction: Second language teacher education. In A. Burns, \& J. Richards (Eds.), The Cambridge guide to second language teacher education (pp. 1-8). Cambridge: Cambridge University Press.

[17] Craft, A. (2000). Continuing professional development: a practical guide for teachers and schools ( $2^{\text {nd }}$ ed.). London: Routledge.

[18] Crandall, J. J., \& Christison, M. (2016). An overview of research in English language teacher education and professional development. In J. Crandall and M. Christison (Eds.), Teacher Education and Professional Development in TESOL: Global Perspectives, (pp. 3-34). Abingdon: Routledge.

[19] Creswell, J. W. (2013). Qualitative inquiry and research design: Choosing among five approaches (3 ${ }^{\text {rd }}$ ed.). London: Sage.

[20] Darling-Hammond, L., \& McLaughlin, M. W. (1995). Policies that support professional development in an era of reform. Phi delta kappan, 76(8), 597-604.

[21] Day, C. (1999). Developing teachers: the challenges of lifelong learning. London: Falmer Press.

[22] Day, C., \& Sachs, J. (2004). Professionalism, performativity and empowerment: discourses in the politics, policies and purposes of continuing professional development. In C. Day \& J. Sachs (Eds.), International handbook on the continuing professional development of teachers (pp. 3-32). Berkshire: McGraw-Hill Education.

[23] Denzin, N. K. \& Lincoln, Y. S. (1998). Introduction: entering the field of qualitative research. In N. K. Denzin, \& Y. S. Lincoln (Eds.), Strategies of qualitative inquiry (pp. 1-34). Thousand Oaks: Sage publications.

[24] Desimone, L. M. (2009). Improving impact studies of teachers' professional development: Toward better conceptualizations and measures. Educational researcher, 38(3), 181-199.

[25] Diaz-Maggioli, G. (2004). Teacher-centered professional development. Alexandria: ASCD.

[26] Elyas, T., \& Al Grigri, W. H. (2014). Obstacles to teaching English in Saudi Arabia public schools: Teachers' and supervisors' perceptions. International Journal of English Language Teaching, 2(3), 74-89

[27] Eraut, M. (2004). Informal learning in the workplace. Studies in continuing education, 26(2), 247-273.

[28] Forde, C., McMahon, M., McPhee, A. D., \& Patrick, F. (2006). Professional development, reflection and enquiry. London: Paul Chapman Publishing.

[29] Freeman, D. (1989). Teacher training, development, and decision making: A model of teaching and related strategies for language teacher education. TESOL quarterly, 23(1), 27-45.

[30] Freeman, D. (2016). Educating second language teachers. Oxford: Oxford University Press.

[31] Fuller, A. (2007). Critiquing theories of learning and communities of practice. In J. Hughes, L. Unwin, N. \& Jewson (Eds.), Communities of practice: Critical perspectives (pp. 17-29). London: Routledge.

[32] Garet, M. S., Porter, A. C., Desimone, L., Birman, B. F., \& Yoon, K. S. (2001). What makes professional development effective? Results from a national sample of teachers. American educational research journal, 38(4), 915-945.

[33] Hayes, D., \& Chang, K. (2012). Theoretical perspectives on and international practice in continuing professional development for English teachers. English Teaching, 67(1), 107-129.

[34] Huberman, M. \& Guskey, T. (1995). Conclusion: the diversities of professional development. In T. Guskey and M. Huberman (Eds), Professional development in education: new paradigms and practices (pp. 269-272). New York: Teachers College Press.

[35] Johnson, K. (2009a). Trends in second language teacher education. In A. Burns, \& J. Richards (Eds.), The Cambridge guide to second language teacher education (pp. 20-29). Cambridge: Cambridge University Press.

[36] Johnson, K. E. (2009b). Second language teacher education: A sociocultural perspective. New York: Routledge.

[37] Kelchtermans, G. (2004). CPD for professional renewal: moving beyond knowledge for practice. In C. Day \& J. Sachs (Eds.), International handbook on the continuing professional development of teachers (pp. 217-237). Berkshire: McGraw-Hill Education.

[38] Kelly, P. (2006). What is teacher learning? A socio - cultural perspective. Oxford review of education, 32(4), 505-519.

[39] Kennedy, A. (2005). Models of continuing professional development: a framework for analysis. Journal of in-service education, 31(2), 235-250.

[40] Kennedy, A. (2014). Understanding continuing professional development: the need for theory to impact on policy and practice. Professional development in education, 40(5), 688-697.

[41] Kumaravadivelu, B. (2003). Beyond methods: macrostrategies for language teaching. New Haven: Yale University Press.

[42] Lave, J., \& Wenger, E. (1991). Situated learning: legitimate peripheral participation. Cambridge: Cambridge university press.

[43] Lieberman, A. (1995). Practices that support teacher development: Transforming conceptions of professional learning. Phi delta kappan, 76(8), 591-596.

[44] Mann, S. (2005). The language teacher's development. Language teaching, 38(3), 103-118.

[45] Marsick, V. J., \& Watkins, K. (2015). Informal and incidental learning in the workplace. New York: Routledge.

[46] Maxwell, J. A. (2005). Qualitative research design: an interactive approach. London: Sage.

[47] McLaughlin, M. (1994). Strategic Sites for Teachers' Professional Development. In P. P. Grimmett, \& J. Neufeld (Eds.), Teacher development and the struggle for authenticity: Professional growth and restructuring in the context of change (pp. 31- 
51). New York: Teachers College Press.

[48] Mitchell, R. (2013). What is professional development, how does it occur in individuals, and how may it be used by educational leaders and managers for the purpose of school improvement? Professional development in education, 39 (3), 387400.

[49] Moskovsky, C., \& Picard, M. (2019). Introduction. In C. Moskovsky \& M. Picard. (Eds.), English as a Foreign Language in Saudi Arabia: New Insights into Teaching and Learning English (pp. 1-3). London: Routledge.

[50] Raza, N. A. (2010). The impact of continuing professional development on EFL teachers employed in federal universities in the United Arab Emirates (Doctoral dissertation). The University of Exeter, Exeter.

[51] Richards, J. C. (1998). Beyond training: perspectives on language teacher education. Cambridge: Cambridge University Press.

[52] Richards, J. C. (2008). Second language teacher education today. RELC journal, 39(2), 158-177.

[53] Richards, J. C. (2011). Exploring teacher competence in language teaching. The language teacher, 35(4), 3-7.

[54] Richards, J. C., \& Farrell, T. S. (2005). Professional development for language teachers: strategies for teacher learning. Cambridge: Cambridge University Press.

[55] Sachs, J. (2016). Teacher professionalism: why are we still talking about it? Teachers and Teaching, 22(4), 413-425.

[56] Sandholtz, J. H. (2002). Inservice training or professional development: Contrasting opportunities in a school/university partnership. Teaching and teacher education, 18(7), 815-830.

[57] Seidman, I. (1998). Interviewing as qualitative research: a guide for researchers in education and the social sciences. New York: Teachers college press.

[58] Smith, K. (2017). Teachers as self-directed learners: active positioning through professional learning. Springer.

[59] Smylie, M. (1995) Teacher learning in the workplace: implications for school reform. In T. Guskey and M. Huberman (Eds), Professional development in education: new paradigms and practices (pp. 92-113). New York: Teachers College Press.

[60] Sywelem, M., \& Witte, J. (2013). Continuing Professional Development: Perceptions of Elementary School Teachers in Saudi Arabia. Journal of Modern Education Review, 12 (3), 881-898.

[61] Taylor, S., Bogdan, R., \& DeVault, M. (2016). Introduction to qualitative research methods: a guidebook and resource (4th ed.). Hoboken: John Wiley \& Sons.

[62] Timperley, H. (2008). Teacher Professional Learning and Development (Educational Practices Series 18). Geneva: International Bureau of Education. http://www.orientation94.org/uploaded/MakalatPdf/Manchurat/EdPractices_18.pdf (accessed 07/02/2020).

[63] Timperley, H. (2011a). Realizing the power of professional learning. England: Open University press.

[64] Timperley, H. (2011b). A background paper to inform the development of a national professional development framework for teachers and school leaders. Melbourne: AITSL.

[65] Villegas-Reimers, E. (2003). Teacher professional development: an international review of the literature. Paris: International Institute for Educational Planning.

[66] Wallace, M. J. (1991). Training foreign language teachers: a reflective approach. Cambridge: Cambridge University Press.

[67] Webster-Wright, A. (2009). Reframing professional development through understanding authentic professional learning. Review of educational research, 79(2), 702-739.

[68] Wenger, E. (1998). Communities of practice: Learning, meaning and identity. Cambridge: Cambridge University Press.

[69] Wenger, E., McDermott, R., \& Snyder, W. (2002). Cultivating communities of practice: a guide to managing knowledge. Boston: Harvard Business Press.

[70] Wilson, E., \& Demetriou, H. (2007). New teacher learning: substantive knowledge and contextual factors. The Curriculum Journal, 18(3), 213-229.

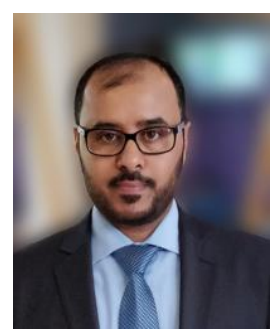

Hamad I. Alshaikhi is an English Language teacher at Al-Qunfuthah Educational Directorate in Saudi Arabia. He obtained his BA in English language and translation from Iman Mohammad ibn Saud University, Riyadh, KSA in 1998, his Master's in English and Arts from king Abdulaziz university, Jeddah, KSA in 2008, and his doctorate in TESOL from the University of Exeter, UK in 2018. He currently holds the position of an English language teacher at ibn Othaimeen Elementary School in Al-Qunfuthah, KSA.

His research interests include language teacher education, professionalism, and second language learning. His previous publications include a co-authored article on the potential of collaborative drawing as a learning tool in multilingual settings. 